\title{
The $\mathrm{A}_{3}$ Adenosine Receptor Agonist IB-MECA Reduces Myocardial Ischemia/Reperfusion Injury in Dogs
}

\author{
John A. Auchampach, Zhe-Dong Ge, Tina C. Wan, Jeannine Moore, and Garrett J. Gross \\ Department of Pharmacology and Toxicology and the Cardiovascular Research Center, Medical \\ College of Wisconsin, Milwaukee, Wisconsin 53226
}

\begin{abstract}
We examined the effect of the $A_{3}$ adenosine receptor (AR) agonist IB-MECA on infarct size in an open-chest anesthetized dog model of myocardial ischemia/reperfusion injury. Dogs were subjected to 60 minutes of left anterior descending (LAD) coronary artery occlusion and 3 hours of reperfusion. Infarct size and regional myocardial blood flow were assessed by macrohistochemical staining with triphenyltetrazolium chloride and radioactive microspheres, respectively. Four experimental groups were studied: vehicle control (50\% DMSO in normal saline), IB-MECA (100 $\mu \mathrm{g} / \mathrm{kg}$ i.v. bolus) given 10 minutes before the coronary occlusion, IBMECA ( $100 \mu \mathrm{g} / \mathrm{kg}$ i.v. bolus) given 5 minutes before initiation of reperfusion, and IB-MECA (100 $\mu \mathrm{g} / \mathrm{kg}$ i.v. bolus) given 10 minutes before coronary occlusion in dogs pretreated 15 minutes earlier with the ATP-dependent potassium $\left(\mathrm{K}_{\mathrm{ATP}}\right)$ channel antagonist glibenclamide $(0.3 \mathrm{mg} / \mathrm{kg}$ i.v. bolus). Administration of IB-MECA had no effect on any hemodynamic parameter measured including heart rate, left ventricular $\mathrm{dP} / \mathrm{dt}$, aortic pressure, LAD coronary blood flow, or coronary collateral blood flow. Nevertheless, pretreatment with IB-MECA before coronary occlusion produced a marked reduction in infarct size ( $\sim 0 \%$ reduction) compared to the control group (13.0 $\pm 3.2 \%$ versus $25.2 \pm 3.7 \%$ of the area-at-risk, respectively). This effect of IB-MECA was blocked completely in dogs pretreated with glibenclamide $(0.3 \mathrm{mg} / \mathrm{kg})$. An equivalent reduction in infarct size was observed when IB-MECA was administered immediately before reperfusion (13.1 \pm $3.9 \%$ ). These results are the first to demonstrate efficacy of an $\mathrm{A}_{3} \mathrm{AR}$ agonist in a large animal model of myocardial infarction by mechanisms that are unrelated to changes in hemodynamic parameters and coronary blood flow. These data also demonstrate in an in vivo model that IBMECA is effective as a cardioprotective agent when administered at the time of reperfusion.
\end{abstract}

\section{Words}

adenosine; $\mathrm{A}_{3}$ receptor; ischemia; heart; infarction

\section{Introduction}

The physiological actions of adenosine are mediated by four adenosine receptor (AR) subtypes designated $\mathrm{A}_{1}, \mathrm{~A}_{2 \mathrm{~A}}, \mathrm{~A}_{2 \mathrm{~B}}$, and $\mathrm{A}_{3}(1,12)$. In the cardiovascular system, $\mathrm{A}_{1} \mathrm{ARs}$ are classically known to be the receptor subtype expressed in cardiac myocytes responsible for the bradycardic and anti-adrenergic actions of adenosine, whereas $\mathrm{A}_{2 \mathrm{~A}} \mathrm{ARs}$ are best known to be expressed in vascular smooth muscle cells where they produce vasodilation. (1) The $A_{3} A R$ is the most recently identified AR subtype (24). Although $A_{3} A R$ message is

Address correspondence to: John A. Auchampach, Ph.D., Pharmacology and Toxicology, Medical College of Wisconsin, 8701 Watertown Plank Road, Milwaukee, Wisconsin 53226, Phone: 414-456-5643, Fax: 414-456-6545, jauchamp@mcw.edu. 
expressed in many different tissues including the heart, its physiological functions remain unknown (24).

$\mathrm{A}_{3} \mathrm{AR}$ agonists such as IB-MECA or CB-MECA ( $N^{6}$-(3-chloro or iodobenzyl)-adenosine-5'$\mathrm{N}$-methylcarboxamide) and the 2-chloro derivative 2-Cl-IB-MECA have been shown to be effective cardioprotective agents in numerous in vitro and in vivo rodent models of ischemia/ reperfusion injury $(5,9,18,19,21,22,26,33,39-44)$. However, no studies have been performed with $\mathrm{A}_{3} \mathrm{AR}$ agonists in large animal models that have variable levels of collateral blood flow similar to that found in humans with coronary artery disease. The present study examined the effect of IB-MECA in an open-chest, anesthetized dog model of infarction.

\section{Methods}

\section{Radioligand Binding Analysis}

Radioligand binding studies were performed with membranes prepared from HEK 293 cells expressing canine $\mathrm{A}_{1}$ or $\mathrm{A}_{3} \mathrm{ARs}$ using [ $\left.{ }^{125} \mathrm{I}\right] \mathrm{AB}-\mathrm{MECA}$ ( $N^{6}$-(4-amino-3-

$\left[{ }^{125}\right.$ I] iodobenzyl)adenosine- $5^{\prime}-N$-methylcarboxamide) as the radioligand $(3,6,41)$. The fulllength canine $A_{1}$ and $A_{3} A R$ were subcloned into the mammalian expression vector pCDNA3.1, transfected into HEK 293 cells using lipofectamine, and then selected with 2 $\mathrm{mg} / \mathrm{ml}$ of G418. Following antibiotic selection, the cells were maintained in DMEM cell culture media containing $10 \%$ fetal bovine serum with $0.6 \mathrm{mg} / \mathrm{ml}$ of G418. Cell membranes were prepared and then incubated with ${ }^{125}$ I-AB-MECA in the presence of inhibitors $(3,6$, $41)$. The binding data were analyzed, as described previously $(3,6)$.

\section{Anesthetized Dog Model}

A standard barbital-anesthetized dog model was employed, as described previously in detail $(2,4)$. All dogs were subjected to 60 minutes of LAD occlusion and 3 hours of reperfusion. Dogs were randomly assigned to one of four experimental groups: vehicle (1 $\mathrm{ml}$ solution of $50 \%$ DMSO in normal saline) given 10 minutes before coronary occlusion, IB-MECA (100 $\mu \mathrm{gkg}$ i.v. bolus) given 10 minutes before coronary occlusion, IB-MECA $(100 \mu \mathrm{g} / \mathrm{kg}$ i.v.bolus) given 5 minutes before reperfusion, and IB-MECA (100 $\mu \mathrm{g} / \mathrm{kg}$ i.v. bolus) given 10 minutes before coronary occlusion in dogs pretreated 15 minutes earlier with the ATPdependent potassium $\left(\mathrm{K}_{\mathrm{ATP}}\right)$ channel antagonist glibenclamide $(0.3 \mathrm{mg} / \mathrm{kg}$ i.v. bolus). Glibenclamide was administered at a dose that we have shown previously to have no effect on infarct size in our dog model. (16) In all of the groups, hemodynamic measurements and arterial blood gases were obtained before occlusion, at 30 minutes of the 60-minute occlusion period, and every hour after reperfusion. Regional myocardial blood flow was measured at 30 minutes during the 60-minute occlusion period and at the end of the experiment. Throughout the ischemia/reperfusion experiments, heart rate was maintained at 150 beats/minute by left atrial pacing.

After 3 hours of reperfusion, the anatomic area-at-risk (AAR) and the non-ischemic area were demarcated by staining with Evan's blue dye $(2,4)$. The hearts were electrically fibrillated, removed, and prepared for infarct size determination (using triphenyltetrazolium choride) and regional myocardial blood flow measurements $(2,4)$. Infarcted and noninfarcted tissues within the area-at-risk were separated and determined gravimetrically. Regional myocardial blood flow was measured by the radioactive microsphere technique (2, 4). Dogs were excluded from the study if subendocardial collateral blood flow was greater than $0.15 \mathrm{ml} / \mathrm{min} / \mathrm{gm}$ or if more than three consecutive attempts were required to convert ventricular fibrillation with low-energy direct current pulses. 


\section{Statistical analyses}

All values are expressed as the mean \pm SEM. Hemodynamic variables were analyzed by two-way repeated measures ANOVA (time and drug treatment) to determine whether there was a main effect of time, a main effect of treatment, or a time-treatment interaction. Infarct sizes and risk region sizes were compared using a one-way ANOVA followed by Student's $t$ test with the Bonferroni correction.

\section{Results}

\section{Pharmacology of IB-MECA}

Based on radioligand binding analysis with recombinant canine receptors, IB-MECA was found to be $\sim 50$-fold selective at binding to the high affinity form of the $\mathrm{A}_{3} \mathrm{AR}$ versus the high affinity form of the $\mathrm{A}_{1} \mathrm{AR}$ (Figure 1). The dissociation constants were calculated to be $0.67 \pm 0.09 \mathrm{nM}$ and $33.8 \pm 2.97 \mathrm{nM}$ for the $\mathrm{A}_{3}$ and $\mathrm{A}_{1} \mathrm{ARs}$, respectively.

In preliminary studies, we examined the actions of IB-MECA on systemic hemodynamic parameters including heart rate, mean arterial blood pressure, left ventricular (LV) pressure, $\mathrm{LV} \mathrm{dP} / \mathrm{dt}$, and LAD coronary artery blood flow in un-paced dogs. Bolus administration of IB-MECA $(100 \mu \mathrm{g} / \mathrm{kg})$ had no effect on any systemic hemodynamic parameter measured for at least 30 minutes (Figure 2). In contrast, an equivalent dose of the $\mathrm{A}_{1} \mathrm{AR}$ agonist CCPA caused short-lived decreases in heart rate, $\mathrm{LV}$ systolic pressure, $\mathrm{LV} \mathrm{dP} / \mathrm{dt}$, and mean arterial blood pressure. CCPA also produced a marked increase in coronary blood flow.

\section{Ischemia/reperfusion data}

A total of 33 dogs were initially included in the infarction study. One dog was excluded from the control group because of intractable ventricular fibrillation and one dog was excluded from the group given IB-MECA at reperfusion because of high collateral blood flow. Thus, a total of $31 \mathrm{dogs}$ were included in the data analysis.

Hemodynamic and regional myocardial blood flow data are shown in Tables 1 and 2. There were no significant differences within or between groups throughout the experiment with regard to heart rate, mean arterial blood pressure, $\mathrm{LV} \mathrm{dP/dt}$, the rate-pressure product or regional myocardial blood flow in either the non-ischemic or ischemic regions, with the exception of a significant increase in mean arterial blood pressure at three hours of reperfusion in the group of dogs treated with IB-MECA before occlusion. There were also no significant differences in blood $\mathrm{pH}, \mathrm{PO}_{2}$, or $\mathrm{PCO}_{2}$ within and between groups at any of the times studied (data not shown).

Figure 3 summarizes the effect of IB-MECA on infarct size. Myocardial infarct size expressed as a percentage of the AAR was reduced significantly $(\sim 40 \% ; \mathrm{P}<0.05)$ in the two groups of dogs treated with IB-MECA (control $=25.2 \pm 3.7 \%$; IB-MECA before occlusion $=13.0 \pm 3.2 \%$, and IB-MECA during reperfusion $=13.1 \pm 3.9 \%$ ). Myocardial infarct size expressed as a percentage of the entire left ventricle was also reduced significantly by IBMECA ( $8.1 \pm 1.4 \%, 4.4 \pm 1.4 \%$, and $4.1 \pm 1.2 \%$, respectively.) Remarkably, the reduction in infarct size was equivalent in magnitude in the group of dogs treated with IB-MECA immediately before reperfusion compared to the pre-treated group. Pre-treating with IBMECA did not reduce infarct size in the group of dogs pretreated with glibenclamide (infarct size as a percent of the AAR $=20.6 \pm 5.6 \%$ and as a percent of the left ventricle $=$ $7.0 \pm 2.0 \%$ ). Among the treatment groups, there were no significant differences with respect to the $\mathrm{LV}$ weight (data not shown). Importantly, there were also no differences among the groups with respect to the size of the AAR (control $=32.0 \pm 3.9 \%$, IB-MECA before 
reperfusion $=32.1 \pm 2.7 \%$, and IB-MECA before reperfusion $=31.4 \pm 3.92 .3 \%$, and IBMECA + glibenclamide $=33.4 \pm 2.3 \%$ of the left ventricle) .

Panels B and C of Figure 3 illustrates the relationship between infarct size and transmural collateral blood flow measured at 30 minutes into the occlusion period in the four experimental groups. In control dogs, there was an inverse relationship between infarct size and collateral blood flow. This relationship was shifted downward in both of the IB-MECAtreated groups, indicating that the reduction in infarct size produced by IB-MECA occurred independently of changes in collateral blood flow. The relationship between infarct size and collateral flow was not shifted by IB-MECA in the group of dogs pretreated with glibenclamide.

\section{Discussion}

Adenosinergic therapy is one of the most promising pharmacological treatments for acute ischemia/reperfusion injury $(28,46)$. Clinically, adenosine has been shown to be effective when used in cardioplegic solutions (30), when co-administered with thrombolytic agents (28), or when administered prior to coronary angioplasty (23). The clinical usefulness of adenosine, however, is limited by its hemodynamic, respiratory, and CNS side effects in addition to its low potency and short half-life. Many of these problems could potentially be avoided by administering synthetic adenosine receptor ligands that are more selective for the individual adenosine receptor subtypes. In experimental animal models, agonists with high affinity for the $\mathrm{A}_{2 \mathrm{~A}} \mathrm{AR}$ including CGS $21680(20)$ and AMP $579(29,38)$ have been shown to be effective at reducing infarct size when administered during reperfusion by reducing neutrophil-mediated injury and inflammation $(8,32,48)$. $\mathrm{A}_{1} \mathrm{AR}$ agonists are highly cardioprotective when administered prior to and during ischemia by producing favorable metabolic effects resulting in preservation of high-energy phosphates (46).

We have recently focused on testing the efficacy of $\mathrm{A}_{3} \mathrm{AR}$ agonists in experimental models of ischemia/reperfusion injury $(5,21,22,41)$. The $\mathrm{A}_{3} \mathrm{AR}$ is the most recently identified subtype of adenosine receptor that is coupled to $\mathrm{G}_{\mathrm{i} / \mathrm{o}}$ inhibitory proteins similar to the $\mathrm{A}_{1} \mathrm{AR}$ (24). Using a chronically instrumented conscious rabbit model, we have observed that pretreatment with IB-MECA $(100 \mu \mathrm{g} / \mathrm{kg})$ produced a significant protective effect against both reversible (myocardial "stunning") and irreversible injury (infarction) $(5,21)$. In these studies, IB-MECA was effective when administered intravenously at a dose that had no effect on heart rate or systemic blood pressure $(5,21)$. The protective effects of IB-MECA were blocked by the non-specific adenosine receptor antagonist 8-sulfophenytheophylline, but not by the $A_{1} A R$ antagonist $N-0861$, implying the involvement of the $A_{3} A R(5,21)$. These results provided evidence that effective cardioprotection can be achieved following systemic administration of an $\mathrm{A}_{3} \mathrm{AR}$ agonist without causing unfavorable hemodynamic consequences.

The results of the present investigation using a dog model of ischemia/reperfusion injury extend these previous observations. Similar to our previous studies in the rabbit, we found that pre-treatment with IB-MECA effectively reduced infarct size from $\sim 25 \%$ of the AAR in control dogs to $\sim 13 \%$ in dogs pre-treated with $100 \mu \mathrm{g} / \mathrm{kg}$ of IB-MECA (Figure 3), a dose also found to be hemodynamically inactive in the dog (Figure 2). The novel aspect of the present study using the dog model is that we were able to provide more detailed assessment of IB-MECA on hemodynamics and coronary artery blood flow. Similar analyses have not been possible in previous studies conducted in rodents. At a dose of $100 \mu \mathrm{g} / \mathrm{kg}$, we found that IB-MECA did not influence blood pressure, $\mathrm{LV}$ pressure, $\mathrm{LV} \mathrm{dP/dt}$, or the rate-pressure product (Table 1 and Figure 2). In addition, IB-MECA had no effect on coronary blood flow (Table 2 and Figure 2). A lack of effect of IB-MECA on hemodynamic parameters was 
apparent during the ischemia/reperfusion studies as well as in preliminary studies in which the effects of IB-MECA were observed for 30 minutes in control barbital-anesthetized dogs. The lack of an effect of IB-MECA on coronary blood flow in these studies is an important observation since it rules against the possibility that it may cause coronary "steal", a complication that has been demonstrated to occur with dipyridamole (47). In addition, the lack of hemodynamic effects suggests that IB-MECA was administered at a dose that did not influence other adenosine receptor subtypes in the heart or vasculature. By comparison, an equivalent dose of the $\mathrm{A}_{1} \mathrm{AR}$ agonist CCPA reduced heart rate, reduced systemic blood pressure, and increased coronary blood flow (Figure 2). Overall, these results clearly suggest that the protective effects of IB-MECA are not dependent on changes in the oxygen supplydemand balance. Rather, they suggest that it acts via a direct cardioprotective mechanism. Previous studies using isolated hearts and isolated cardiomyocytes $(9,18,19,26,33,39,40$, 42-44) have suggested that $A_{3} A R s$ are expressed in the myocardium and that they couple to cardioprotective signaling mechanisms similar to those coupled to the $A_{1} A R$, presumably the ATP-sensitive potassium channel. We predict that pre-treatment with IB-MECA provided protection in our dog model by a comparable mechanism. This theory is supported by the observation that the reduction in infarct size provided by pre-treating with IB-MECA was blocked completely by glibenclamide. One interesting aspect of the present investigation is that subendocardial blood flow was increased after three hours of reperfusion in the ischemic-reperfused myocardium in control animals (Table 2). These data indicate that hyperemia developed in the subendocardial region, which we believe is related to the short period of ischemia utilized in our protocol. Importantly, the distribution of blood flow across the myocardium in the ischemic-reperfused region was identical in the two groups of dogs treated with IB-MECA, indicating further that IB-MECA had no effect on blood flow at the dose utilized in our investigation.

The second novel aspect of this work is that we found that IB-MECA was effective when administered at the time of reperfusion. In fact, we found that IB-MECA produced an equivalent reduction in infarct size whether it was administered 10 minutes before the onset of ischemia or whether it was administered 5 minutes before the release of the occlusion. These results suggest that, in addition to exerting favorable effects during ischemia, IBMECA produced beneficial actions that attenuated reperfusion injury. We predict that there are two potential mechanisms by which IB-MECA may have reduced reperfusion injury. The first is via an anti-inflammatory mechanism. Jordan and colleagues (20) have previously observed using an in vitro assay that nanomolar concentrations of Cl-IB-MECA reduced adhesion of neutrophils to coronary artery segments via actions on the endothelium rather than on the neutrophils. This effect of Cl-IB-MECA to reduce neutrophil adhesion was attributed to the $A_{3} A R$, since the $A_{3} A R$ antagonist MRS 1220 (but not $A_{1}$ or $A_{2 A} A R$ antagonists) antagonized its effects completely.(20) These investigators (20) further demonstrated that treatment with Cl-IB-MECA reduced contractile dysfunction and neutrophil margination in an isolated rabbit heart model of neutrophil-mediated reperfusion injury. These observations, taken together with additional work by other investigators demonstrating that $\mathrm{A}_{3} \mathrm{AR}$ agonists reduce the expression of pro-inflammatory cytokines (35, 36) and reduce neutrophil function,(7) provide additional support for the idea that IB-MECA reduced infarct size in the present investigation by an anti-inflammatory effect. A second complementary mechanism by which IB-MECA may have reduced infarct size, however, is by inhibiting apoptosis, since the $\mathrm{A}_{3} \mathrm{AR}$ is known to be capable of coupling to two well known cell survival signaling pathways including the phosphatidylinositol-3' (PI-3) kinase/ akt kinase pathway $(14,37)$ and the Ras/Raf-1/MEK/Erk 1/2 pathway (37). This potential mechanism is supported by the results of Maddock and colleagues,(27) who reported that Cl-IB-MECA reduced apoptosis of isolated rat cardiac myocytes subjected to simulated ischemia when administered during re-oxygenation. 
IB-MECA was originally shown to be $\sim 50$-fold selective for rat $\mathrm{A}_{3} \mathrm{ARs}$ versus rat $\mathrm{A}_{1}$ and $A_{2 A}$ ARs (13). Using canine adenosine receptors expressed in HEK 293 cells, we have also found in the present investigation that IB-MECA is $\sim 50$-fold more potent at binding to the canine $A_{3} A R$ versus the canine $A_{1} A R$ (Figure 1). These binding data coupled with the observation that IB-MECA was hemodynamically inactive in our in vivo studies suggest that the $A_{3} A R$ was the primary site of IB-MECA to reduce infarct size. It should be noted, however, that Linden's group (31) has recently provided evidence that $\mathrm{A}_{3} \mathrm{AR}$ agonists including Cl-IB-MECA may bind to $\mathrm{A}_{2 \mathrm{~A}} \mathrm{ARs}$ with higher affinity than originally appreciated. Furthermore, this group has suggested (25) that $\mathrm{A}_{2 \mathrm{~A}} \mathrm{AR}$ agonists are effective anti-inflammatory/tissue-protective agents at low, non-hypotensive doses due to efficient coupling of $\mathrm{A}_{2 \mathrm{~A}} \mathrm{ARs}$ in immune cells. It remains possible, therefore, that IB-MECA was effective in the present investigation via an anti-inflammatory effect mediated via the $\mathrm{A}_{2 \mathrm{~A}} \mathrm{AR}$, or via a combined effect mediated through the $\mathrm{A}_{2 \mathrm{~A}}$ and $\mathrm{A}_{3} \mathrm{ARs}$. The large size of the dog precludes the use of selective antagonists to verify the involvement of individual $A R$ subtypes in the present investigation. In preliminary studies (15), however, we have observed that Cl-IB-MECA does not reduce infarct size in mice lacking $\mathrm{A}_{3} \mathrm{ARs}\left(\mathrm{A}_{3} \mathrm{AR}\right.$ gene "knock-out" mice), supporting a role for these agents acting to modulate ischemia/ reperfusion injury by interacting with the $\mathrm{A}_{3} \mathrm{AR}$.

The effect of $\mathrm{A}_{3} \mathrm{AR}$ agonists on hemodynamics differs among species. Although we have observed that IB-MECA (and Cl-IB-MECA) has no hemodynamic effects in rabbits and dogs, Cl-IB-MECA and APNEA ( $N^{6}$-(3-aminophenylethyl)adenosine) have been reported to cause a short-lived hypotension without any change in heart rate in rats and mice $(11,17$, 45). The hypotensive actions of $A_{3} A R$ agonists in rodents is likely an effect mediated via the release of vasoactive mediators from mast cells since: 1) a concomitant increase in plasma histamine levels occurs in rodents (but not in rabbits (5)) in response to $\mathrm{A}_{3} \mathrm{AR}$ agonists (11, 45), 2) stimulatory $A_{3} A R s$ have been identified on rodent mast cells (34), and 3) the hypotensive actions of $\mathrm{A}_{3} \mathrm{AR}$ agonists are antagonized by mast cell stablizers including sodium cromoglycate and lodoxamide (17). We have previously demonstrated that $\mathrm{A}_{2 \mathrm{~B}} \mathrm{ARs}$ rather than the $\mathrm{A}_{3} \mathrm{AR}$ modulate degranulation of canine mast cells (3). Feoktistov and Biaggioni (10) have demonstrated that $\mathrm{A}_{2 \mathrm{~B}} \mathrm{ARs}$ regulate human mast cell functions. Hence, differences in the adenosine receptors that regulate mast cells may underlie the variable hemodynamic actions of $\mathrm{A}_{3} \mathrm{AR}$ agonists observed between rodents and other mammalian species.

In conclusion, we have demonstrated in a large animal model that the $\mathrm{A}_{3} \mathrm{AR}$ agonist IBMECA effectively reduces infarct size when given before ischemia or when given during reperfusion. The protective actions of IB-MECA occurred without altering systemic hemodynamics or coronary blood flow. These results suggest that $\mathrm{A}_{3} \mathrm{AR}$ agonists may be useful cardioprotective agents for the treatment of acute myocardial ischemia/reperfusion injury

\section{Acknowledgments}

The authors thank Ana Hsu for assistance with the preparation of the figures. This work was supported by NIH R01 grant HL 60051, HL 08311, and a Postdoctoral Fellowship from the American Heart Association (Dr. Ge).

\section{References}

1. Auchampach JA, Bolli R. Adenosine receptor subtypes in the heart: therapeutic opportunities and challenges. Am J Physiol. 1999; 276:H1113-6. [PubMed: 10070100]

2. Auchampach JA, Gross GJ. Reduction in myocardial infarct size by the new potassium channel opener bimakalim. J Cardiovasc Pharmacol. 1994; 23:554-61. [PubMed: 7516004] 
3. Auchampach JA, Jin X, Wan TC, Caughey GH, Linden J. Canine mast cell adenosine receptors: cloning and expression of the $\mathrm{A}_{3}$ receptor and evidence that degranulation is mediated by the $\mathrm{A}_{2 \mathrm{~B}}$ receptor. Mol Pharmacol. 1997; 52:846-60. [PubMed: 9351976]

4. Auchampach JA, Pieper GM, Cavero I, Gross GJ. Effect of the platelet-activating factor antagonist RP 59227 (Tulopafant) on myocardial ischemia/reperfusion injury and neutrophil function. Basic Res Cardiol. 1998; 93:361-71. [PubMed: 9833148]

5. Auchampach JA, Rizvi A, Qiu Y, Tang XL, Maldonado C, Teschner S, Bolli R. Selective activation of $\mathrm{A}_{3}$ adenosine receptors with $N^{6}$-(3-iodobenzyl)adenosine-5' $N$-methyluronamide protects against myocardial stunning and infarction without hemodynamic changes in conscious rabbits. Circ Res. 1997; 80:800-9. [PubMed: 9168782]

6. Black RG Jr, Guo Y, Ge ZD, Murphree SS, Prabhu SD, Jones WK, Bolli R, Auchampach JA. Gene dosage-dependent effects of cardiac-specific overexpression of the $\mathrm{A}_{3}$ adenosine receptor. Circ Res. 2002; 91:165-72. [PubMed: 12142350]

7. Bouma MG, Jeunhomme TM, Boyle DL, Dentener MA, Voitenok NN, van den Wildenberg FA, Buurman WA. Adenosine inhibits neutrophil degranulation in activated human whole blood: involvement of adenosine $A_{2}$ and $A_{3}$ receptors. J Immunol. 1997; 158:5400-8. [PubMed: 9164961]

8. Budde JM, Velez DA, Zhao Z, Clark KL, Morris CD, Muraki S, Guyton RA, Vinten-Johansen J. Comparative study of AMP579 and adenosine in inhibition of neutrophil-mediated vascular and myocardial injury during 24 h of reperfusion. Cardiovasc Res. 2000; 47:294-305. [PubMed: 10946066]

9. Carr CS, Hill RJ, Masamune H, Kennedy SP, Knight DR, Tracey WR, Yellon DM. Evidence for a role for both the adenosine $A_{1}$ and $A_{3}$ receptors in protection of isolated human atrial muscle against simulated ischaemia. Cardiovasc Res. 1997; 36:52-9. [PubMed: 9415272]

10. Feoktistov I, Biaggioni I. Adenosine $A_{2 B}$ receptors evoke interleukin-8 secretion in human mast cells. An enprofylline-sensitive mechanism with implications for asthma. J Clin Invest. 1995; 96:1979-86. [PubMed: 7560091]

11. Fozard JR, Pfannkuche HJ, Schuurman HJ. Mast cell degranulation following adenosine $\mathrm{A}_{3}$ receptor activation in rats. Eur J Pharmacol. 1996; 298:293-7. [PubMed: 8846829]

12. Fredholm BB. Purinoceptors in the nervous system. Pharmacol Toxicol. 1995; 76:228-39. [PubMed: 7617551]

13. Gallo-Rodriguez C, Ji XD, Melman N, Siegman BD, Sanders LH, Orlina J, Fischer B, Pu Q, Olah $\mathrm{ME}$, van Galen PJ, et al. Structure-activity relationships of $N^{6}$-benzyladenosine-5'-uronamides as A $_{3}$-selective adenosine agonists. J Med Chem. 1994; 37:636-46. [PubMed: 8126704]

14. Gao Z, Li BS, Day YJ, Linden J. A3 adenosine receptor activation triggers phosphorylation of protein kinase $\mathrm{B}$ and protects rat basophilic leukemia $2 \mathrm{H} 3$ mast cells from apoptosis. Mol Pharmacol. 2001; 59:76-82. [PubMed: 11125027]

15. Ge ZD, Peart J, Auchampach JA. Effect of the $\mathrm{A}_{3}$ adenosine receptor agonist Cl-IB-MECA on ischemia/reperfusion injury in $\mathrm{A}_{3}$ receptor gene "knock-out" mice. FASEB J. in press.

16. Gross GJ, Auchampach JA. Blockade of ATP-sensitive potassium channels prevents myocardial preconditioning in dogs. Circ Res. 1992; 70:223-33. [PubMed: 1310443]

17. Hannon JP, Pfannkuche HJ, Fozard JR. A role for mast cells in adenosine $\mathrm{A}_{3}$ receptor-mediated hypotension in the rat. Br J Pharmacol. 1995; 115:945-52. [PubMed: 7582525]

18. Harrison GJ, Cerniway RJ, Peart J, Berr SS, Ashton K, Regan S, Paul Matherne G, Headrick JP. Effects of $\mathrm{A}_{3}$ adenosine receptor activation and gene knock-out in ischemic-reperfused mouse heart. Cardiovasc Res. 2002; 53:147-55. [PubMed: 11744023]

19. Jordan JE V, Thourani H, Auchampach JA, Robinson JA, Wang NP, Vinten-Johansen J. A 3 adenosine receptor activation attenuates neutrophil function and neutrophil-mediated reperfusion injury. Am J Physiol. 1999; 277:H1895-905. [PubMed: 10564145]

20. Jordan JE, Zhao ZQ, Sato H, Taft S, Vinten-Johansen J. Adenosine $A_{2}$ receptor activation attenuates reperfusion injury by inhibiting neutrophil accumulation, superoxide generation and coronary endothelial adherence. J Pharmacol Exp Ther. 1997; 280:301-9. [PubMed: 8996210]

21. Kodani E, Bolli R, Tang XL, Auchampach JA. Protection of IB-MECA against myocardial stunning in conscious rabbits is not mediated by the $\mathrm{A}_{1}$ adenosine receptor. Basic Res Cardiol. 2001; 96:487-96. [PubMed: 11605996] 
22. Kodani E, Shinmura K, Xuan YT, Takano H, Auchampach JA, Tang XL, Bolli R. Cyclooxygenase-2 does not mediate late preconditioning induced by activation of adenosine $\mathrm{A}_{1}$ or $\mathrm{A}_{3}$ receptors. Am J Physiol Heart Circ Physiol. 2001; 281:H959-68. [PubMed: 11454603]

23. Leesar MA, Stoddard M, Ahmed M, Broadbent J, Bolli R. Preconditioning of human myocardium with adenosine during coronary angioplasty. Circulation. 1997; 95:2500-7. [PubMed: 9184580]

24. Linden J. Cloned adenosine $A_{3}$ receptors: pharmacological properties, species differences and receptor functions. Trends Pharmacol Sci. 1994; 15:298-306. [PubMed: 7940998]

25. Linden J. Molecular approach to adenosine receptors: receptor-mediated mechanisms of tissue protection. Annu Rev Pharmacol Toxicol. 2001; 41:775-87. [PubMed: 11264476]

26. Liu GS, Richards SC, Olsson RA, Mullane K, Walsh RS, Downey JM. Evidence that the adenosine $\mathrm{A}_{3}$ receptor may mediate the protection afforded by preconditioning in the isolated rabbit heart. Cardiovasc Res. 1994; 28:1057-61. [PubMed: 7954592]

27. Maddock HL, Mocanu MM, Yellon DM. Adenosine $\mathrm{A}_{3}$ receptor activation protects the myocardium from reperfusion/reoxygenation injury. Am J Physiol Heart Circ Physiol. 2002; 283:H1307-13. [PubMed: 12234780]

28. Mahaffey KW, Puma JA, Barbagelata NA, DiCarli MF, Leesar MA, Browne KF, Eisenberg PR, Bolli R, Casas AC, Molina-Viamonte V, Orlandi C, Blevins R, Gibbons RJ, Califf RM, Granger $\mathrm{CB}$. Adenosine as an adjunct to thrombolytic therapy for acute myocardial infarction: results of a multicenter, randomized, placebo-controlled trial: the Acute Myocardial Infarction STudy of ADenosine (AMISTAD) trial. J Am Coll Cardiol. 1999; 34:1711-20. [PubMed: 10577561]

29. McVey MJ, Smits GJ, Cox BF, Kitzen JM, Clark KL, Perrone MH. Cardiovascular pharmacology of the adenosine $\mathrm{A}_{1} / \mathrm{A}_{2}$-receptor agonist AMP 579: coronary hemodynamic and cardioprotective effects in the canine myocardium. J Cardiovasc Pharmacol. 1999; 33:703-10. [PubMed: 10226856]

30. Mentzer RM Jr, Rahko PS, Molina-Viamonte V, Canver CC, Chopra PS, Love RB, Cook TD, Hegge JO, Lasley RD. Safety, tolerance, and efficacy of adenosine as an additive to blood cardioplegia in humans during coronary artery bypass surgery. Am J Cardiol. 1997; 79:38-43. [PubMed: 9223362]

31. Murphree LJ, Marshall MA, Rieger JM, MacDonald TL, Linden J. Human A 2 A adenosine receptors: high-affinity agonist binding to receptor-G protein complexes containing $\mathrm{G}_{\beta 4}$. Mol Pharmacol. 2002; 61:455-62. [PubMed: 11809871]

32. Nakamura M, Zhao ZQ, Clark KL, Velez DV, Guyton RA, Vinten-Johansen J. A novel adenosine analog, AMP579, inhibits neutrophil activation, adherence and neutrophil-mediated injury to coronary vascular endothelium. Eur J Pharmacol. 2000; 397:197-205. [PubMed: 10844114]

33. Peart J, Flood A, Linden J, Matherne GP, Headrick JP. Adenosine-mediated cardioprotection in ischemic-reperfused mouse heart. J Cardiovasc Pharmacol. 2002; 39:117-29. [PubMed: 11743234]

34. Ramkumar V, Stiles GL, Beaven MA, Ali H. The $\mathrm{A}_{3}$ adenosine receptor is the unique adenosine receptor which facilitates release of allergic mediators in mast cells. J Biol Chem. 1993; 268:16887-90. [PubMed: 8349579]

35. Sajjadi FG, Takabayashi K, Foster AC, Domingo RC, Firestein GS. Inhibition of TNF-a expression by adenosine: role of $\mathrm{A}_{3}$ adenosine receptors. J Immunol. 1996; 156:3435-42. [PubMed: 8617970]

36. Salvatore CA, Tilley SL, Latour AM, Fletcher DS, Koller BH, Jacobson MA. Disruption of the $\mathrm{A}_{3}$ adenosine receptor gene in mice and its effect on stimulated inflammatory cells. J Biol Chem. 2000; 275:4429-34. [PubMed: 10660615]

37. Schulte G, Fredholm BB. Signaling pathway from the human adenosine $A_{3}$ receptor expressed in chinese hamster ovary cells to the extacellular signal-regulated kinase 1/2. Mol Pharmacol. 2002; 62:1137-1146. [PubMed: 12391277]

38. Smits GJ, McVey M, Cox BF, Perrone MH, Clark KL. Cardioprotective effects of the novel adenosine $\mathrm{A}_{1} / \mathrm{A}_{2}$ receptor agonist AMP 579 in a porcine model of myocardial infarction. $\mathrm{J}$ Pharmacol Exp Ther. 1998; 286:611-8. [PubMed: 9694911] 
39. Stambaugh K, Jacobson KA, Jiang JL, Liang BT. A novel cardioprotective function of adenosine $\mathrm{A}_{1}$ and $\mathrm{A}_{3}$ receptors during prolonged simulated ischemia. Am J Physiol. 1997; 273:H501-5. [PubMed: 9249524]

40. Strickler J, Jacobson KA, Liang BT. Direct preconditioning of cultured chick ventricular myocytes. Novel functions of cardiac adenosine $A_{2 A}$ and $A_{3}$ receptors. J Clin Invest. 1996; 98:1773-9. [PubMed: 8878427]

41. Takano H, Bolli R, Black RG Jr, Kodani E, Tang XL, Yang Z, Bhattacharya S, Auchampach JA. $\mathrm{A}_{1}$ or $\mathrm{A}_{3}$ adenosine receptors induce late preconditioning against infarction in conscious rabbits by different mechanisms. Circ Res. 2001; 88:520-8. [PubMed: 11249876]

42. Thourani VH, Nakamura M, Ronson RS, Jordan JE, Zhao ZQ, Levy JH, Szlam F, Guyton RA, Vinten-Johansen J. Adenosine A3-receptor stimulation attenuates postischemic dysfunction through K $\mathrm{ATP}_{\mathrm{T}}$ channels. Am J Physiol. 1999; 277:H228-35. [PubMed: 10409201]

43. Thourani VH, Ronson RS, Jordan JE, Guyton RA, Vinten-Johansen J. Adenosine A 3 pretreatment before cardioplegic arrest attenuates postischemic cardiac dysfunction. Ann Thorac Surg. 1999; 67:1732-7. [PubMed: 10391283]

44. Tracey WR, Magee W, Masamune H, Oleynek JJ, Hill RJ. Selective activation of adenosine $A_{3}$ receptors with $N^{6}$-(3-chlorobenzyl)-5'- $N$-methylcarboxamidoadenosine (CB-MECA) provides cardioprotection via $\mathrm{K}_{\mathrm{ATP}}$ channel activation. Cardiovasc Res. 1998; 40:138-45. [PubMed: 9876326]

45. Van Schaick EA, Jacobson KA, Kim HO, APIJ, Danhof M. Hemodynamic effects and histamine release elicited by the selective adenosine $\mathrm{A}_{3}$ receptor agonist 2-Cl-IB-MECA in conscious rats. Eur J Pharmacol. 1996; 308:311-4. [PubMed: 8858305]

46. Vinten-Johansen J V, Thourani H, Ronson RS, Jordan JE, Zhao ZQ, Nakamura M, Velez D, Guyton RA. Broad-spectrum cardioprotection with adenosine. Ann Thorac Surg. 1999; 68:1942-8. [PubMed: 10585108]

47. Winbury MM, Howe BB, Hefner MA. Effect of nitrates and other coronary dilators on large and small coronary vessels: an hypothesis for the mechanism of action of nitrates. J Pharmacol Exp Ther. 1969; 168:70-95. [PubMed: 4978326]

48. Zhao ZQ, Clark KL, Wang NP, Velez DA, Guyton RA, Vinten-Johansen J. Comparison of AMP 579 and adenosine in inhibition of cell-cell interaction between human neutrophil and vascular endothelial. Drug Dev Res. 2000; 49:266-272. 


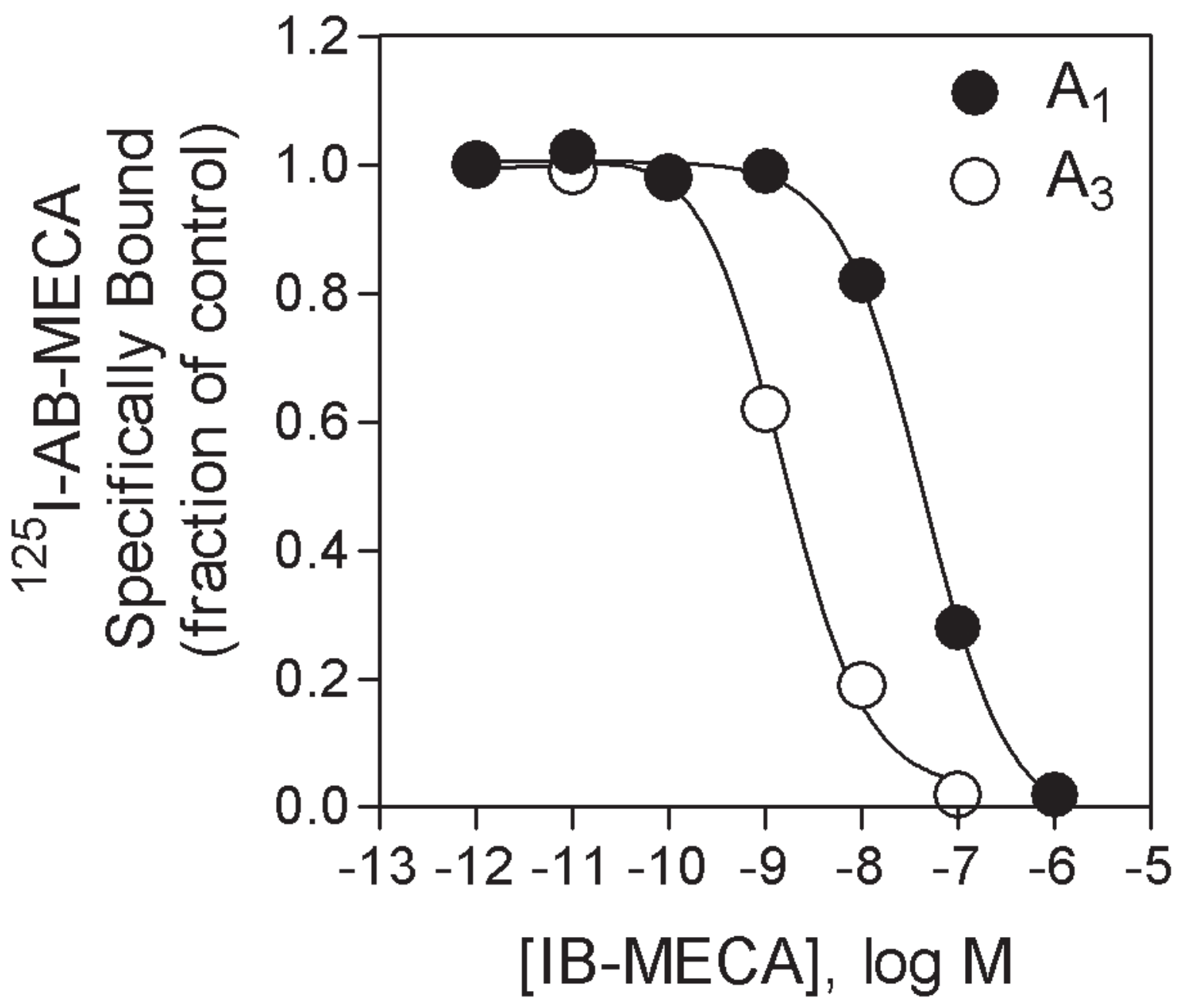

Figure 1.

Competition for $\left[{ }^{125} \mathrm{I}\right] \mathrm{AB}-\mathrm{MECA}$ binding to HEK 293 cell membranes expressing recombinant canine $\mathrm{A}_{1}$ or $\mathrm{A}_{3} \mathrm{ARs}$. Binding is plotted as a fraction of control specific binding. The binding of $\left[{ }^{125} \mathrm{I}\right] \mathrm{AB}-\mathrm{MECA}$ was fitted to one or two binding sites as described previously $(3,6)$. Dissociation constants for the high affinity binding sites were calculated to be $0.67 \pm 0.09 \mathrm{nM}$ for the $\mathrm{A}_{1} \mathrm{AR}$ and $33.8 \pm 2.97$ for the $\mathrm{A}_{3} \mathrm{AR}(3,6)$. Vales are the mean \pm SEM of triplicate determinations. Protein, $50 \mu \mathrm{g} /$ incubation; $\left[{ }^{125} \mathrm{I}\right] \mathrm{AB}-\mathrm{MECA}, \sim 100,000$ cpm $(\sim 0.3 \mathrm{nM}) /$ incubation. 


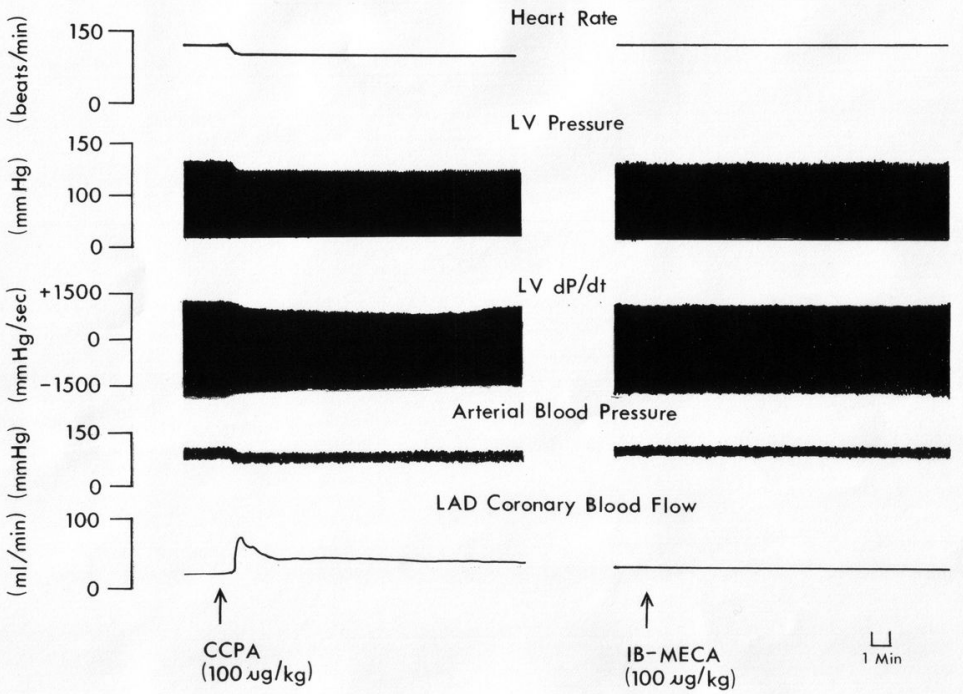

Figure 2.

Comparison of the hemodynamic actions of CCPA $(100 \mu \mathrm{g} / \mathrm{kg}$ i.v. bolus $)$ and IB-MECA $(100 \mu \mathrm{g} / \mathrm{kg}$ i.v. bolus) in anesthetized dogs. 
A.

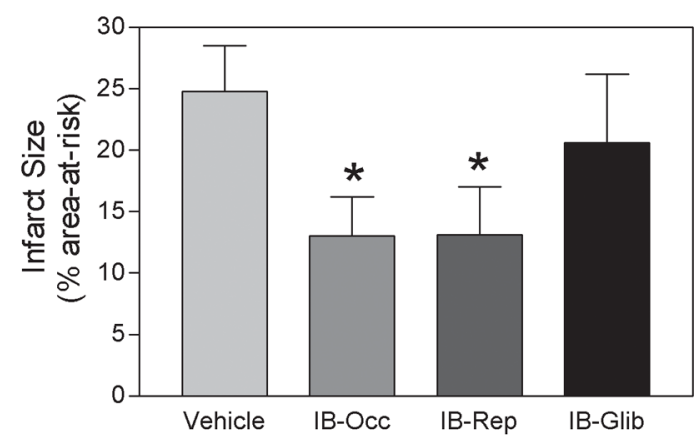

B.

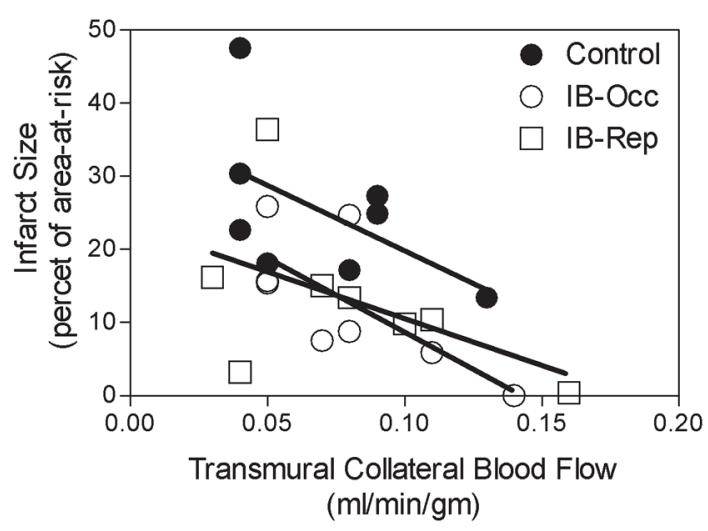

c.

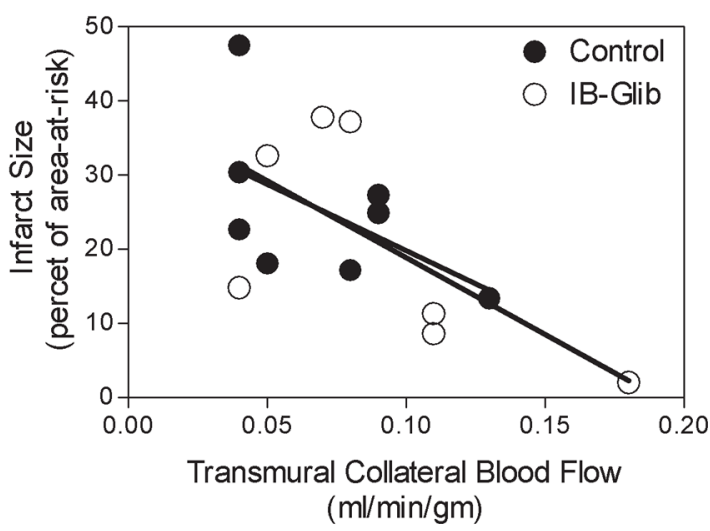

Figure 3.

Myocardial infarct size data. Panel A. Infarct size expressed as a percentage of the area-atrisk in the four groups of dogs. Values are the mean \pm SEM. $n=7-8 /$ group. Panels $\mathbf{B}$ and C. Relationship between transmural collateral blood flow and infarct size expressed as a percentage of the area-at-risk in the four groups of dogs. 


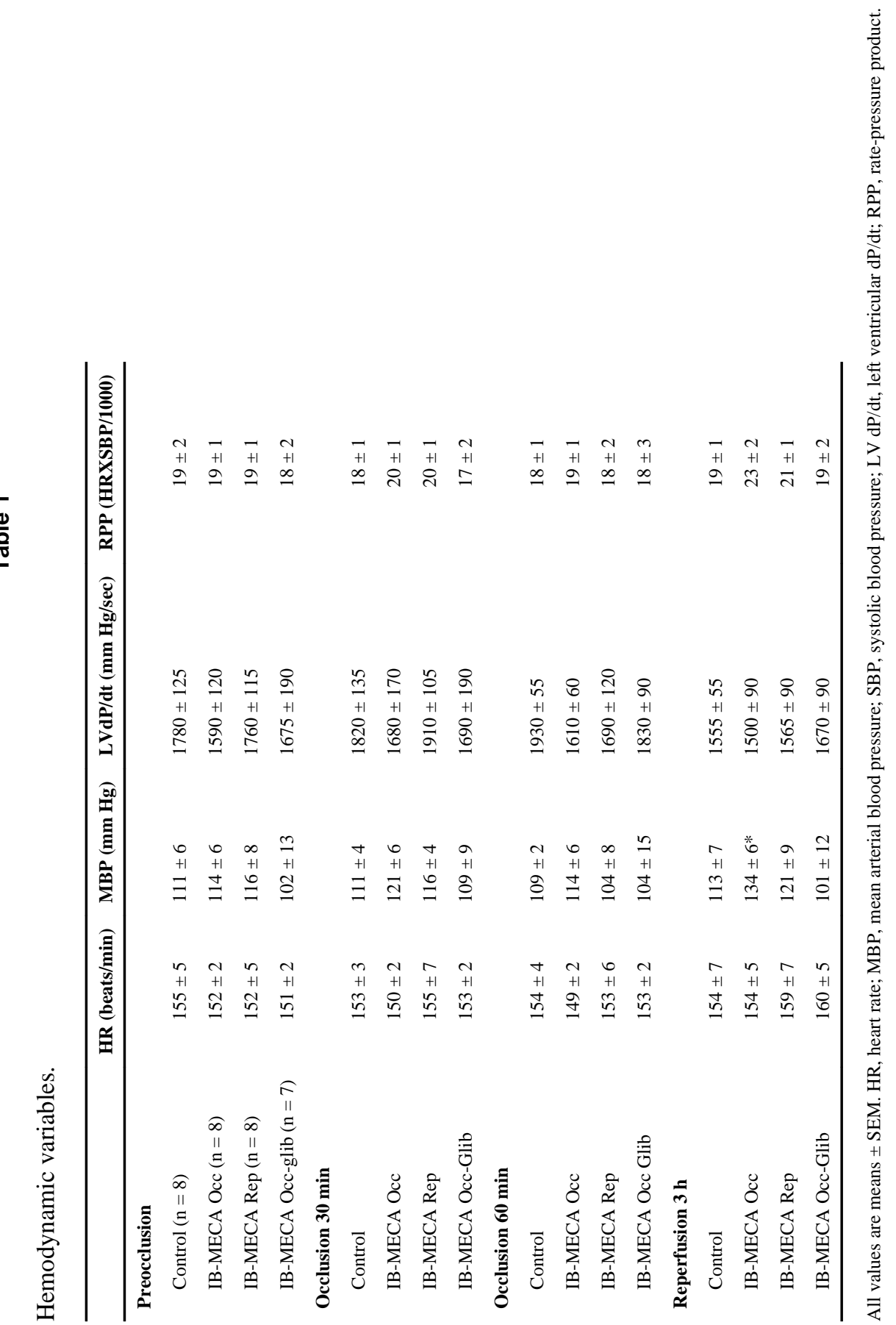


